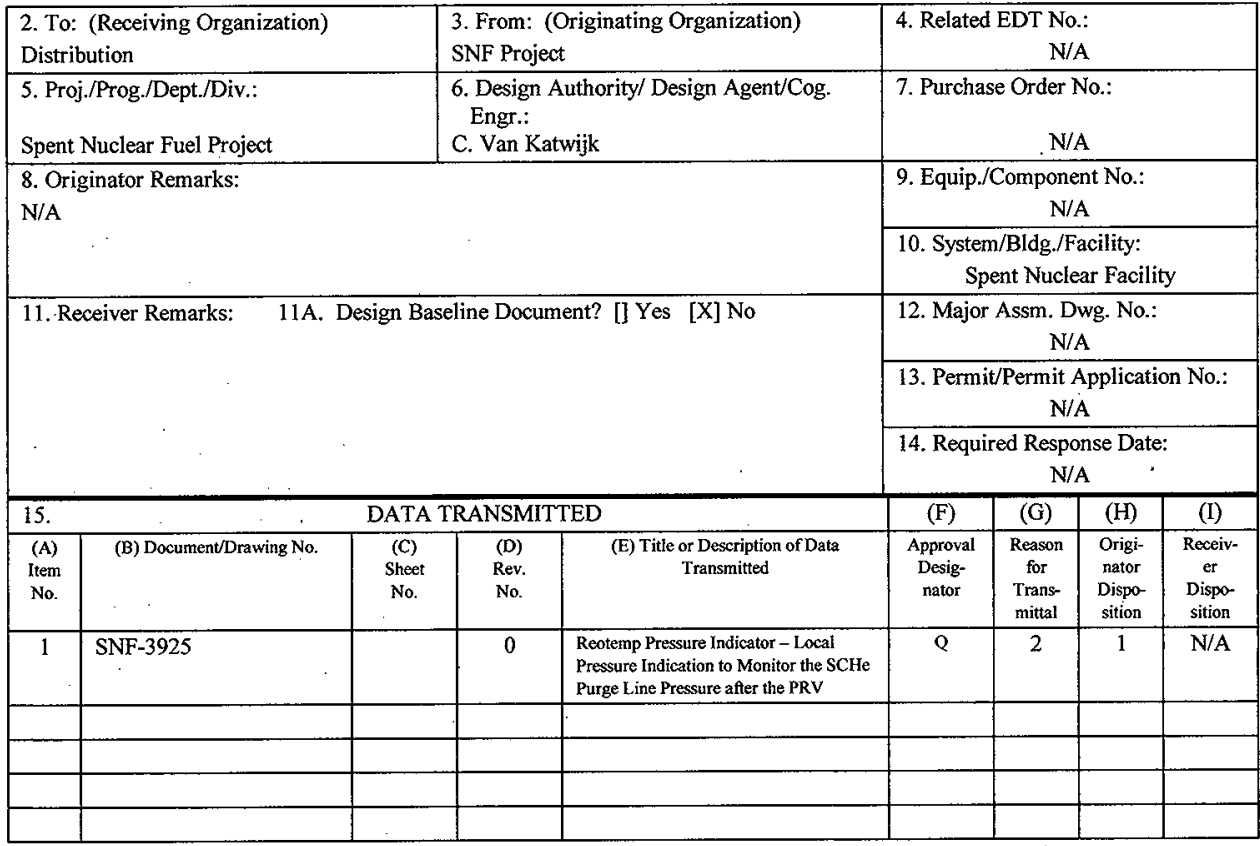

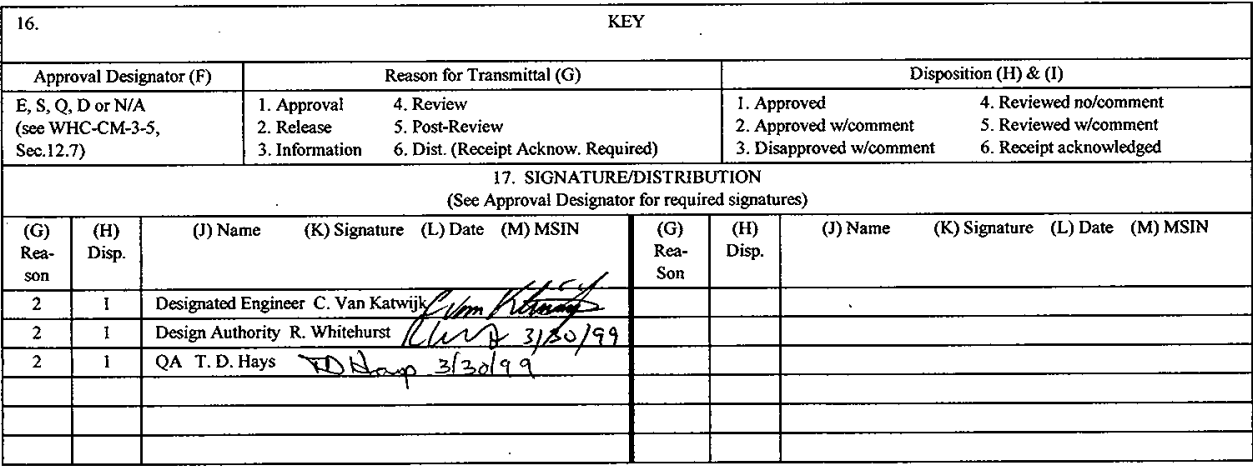
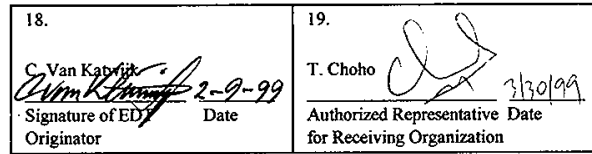

20. Chot
$\begin{aligned} & \text { Design Authorityl } \\ & \text { Cognizant Manager }\end{aligned}$

21. DOE APPROVAL (if required) Ctrl. No.

[] Approved

¿ Approved w/comments

[I Disapproved w/comments 


\title{
Reotemp Pressure Indicator - Local Pressure Indication to Monitor the SCHe Purge Line Pressure After the PRV
}

\author{
Carl Van Katwijk \\ Numatec Hanford Co, Richiand, WA 99352 \\ U.S. Department of Energy Contract DE-AC06-96RL13200
}

EDT/ECN: 626274

Org Code: $2 \mathrm{G} 300$

B\&R Code: $39 \mathrm{EW} 40400$
UC: 620

Charge Code: $105559 / \mathrm{A} 000$

Total Pages: $; 3$

Key Words: Pressure Indicators - Purge Lines

Abstract: Reotemp Pressure Indicator - Local Pressure Indication to Monitor the SCHe Purge Line Pressure After the PRV CGI-SNF-D-13-P5-028

TRADEMARK DISCLAIMER. Reference herein to any specific commercial product, process, or service by trade name, trademark, manufacturer, or otherwise, does not necessarily constitute or imply its endorsement, recommendation, or favoring by the United States Government or any agency thereof or its contractors or subcontractors.

Printed in the United States of America. To obtain copies of this document, contact: Document Control Services, P.O. Box 950, Mailstop H6-08, Richland WA 99352, Phone (509) 372-2420; Fax (509) 376-4989.

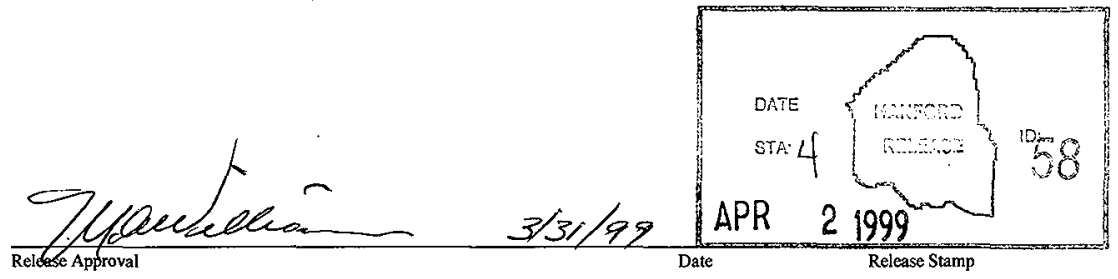

\section{Approved for Public Release}


Commercial Grade Item Upgrade Dedication Form

ECNNo.NA CGINo.CGI-SNF-D-13-P5-028

Rev. No. 0

Title: REOTEMP PRESSURE INDICATOR-LOCAL PRESSURE INDICATION TO MONITOR THE SCHE PURGE LINE PRESSURE AFTER THE PRV

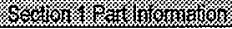

Item No: NA

Manufacturer.

Supplier:

Mif. Part/Model No.:

Supplier's PN:

Part Description:

End Use Description:

-.6.t.

\begin{tabular}{l|l|l|l} 
Equipment No:: SCHe-PI- & Specification No:: W-441- & Manufacturer: Reotemp & Past P.O. No.: NA
\end{tabular}

$5 * 09,5 * 28,5 * 48$,

$5 * 68$

Manufacturer's Part/ Model

No.: PR-25-S-1-A-4-

P15-D

P5, Rev. 2

Instruments

Equipment Supplier (if different from manufacturer): TBD

Equip. Supplier's Part No.:

NA

Component Description: These 0-15 psig range pressure indicators are located in the SCHe purge lines downstream of the PRVs. PI 5*09 and PI 5*28 monitor the 7 psig pressure purge lines and PI $5^{*} 48$ and $5^{*} 68$ monitor the 2 psig pressure purge lines.

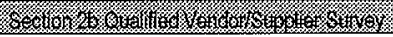

1. Is the ltem available from a catalog from a qualified NQA1 of Engineer or BTR)?

[ ] YES (go to \#2 below)

Cin $12121 / 28$

[X] No (go to procedure step 5.3.2, proceed to decicate item.)

2. List of Candidate qualified suppliers of 1800 supplian $12 / 2,198$ company name and type contact name $C K / 2 / 2 / 98$ phone

NA

Recommended Procurement Strategy (coordinate with project CGl interface Engineer or BTR):

3. NA

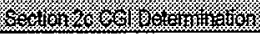

1. Question \#1: Is the Item subject to design or specification requirements that are unique to nuclear facilities or activities?

[ 1 YES (the ltem is not commercial grade)

[X] No (continue)

2. Question \#2: Is the item used in applications other than nuclear facilities or activities?

[ ] NO (the item is not commercial grade)

[X] YES (continue) 


\section{ECN No. NA \\ CGI No. CGI-SNF-D-13-PS-028 \\ Title: REOTEMP PRESSURE INDICATOR - LOCAL PRESSURE INDICATION TO MONITOR THE SCFI PURGE LINE PRESSURE AFTER THE PRV}

Page 2 of 12

3. Question \#3: Is the Item ordered from manufacturer/supplier on the basis or specifications set forth in the manufacturers catalog?

1 I NO (the lfem is not commercial grade)

[X] YES (continue)

[X] All three criteria have been satisfied. The ltem meets the definition of commercial grade.

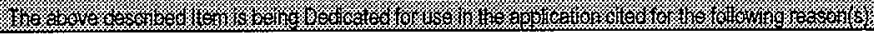

[X] Item is being purchased from a non ESL manufacturer supplier as commercial grade to be used in a Safety Class application.

1 ] Item is being purchased from a non ESL manufacturer supplier as commercial grade to be used in a Safety Significant application.

[ ] Item was purchased from a non ESL manufacturer supplier as commercial grade to be used in a Safety Class application.

[ ] Item was purchased from a non ESL manufacturer supplier as commercial grade to be used in a Safety Significant application.

[ ] Other ('ike-for-like', similar, substitution, replacement evaluation)

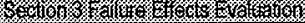

\section{A. Part/Component Safety Function:}

1. Pressure boundary integrity - prevents helium leakage from the SCHe system.

\section{Maintain pressure boundary after seismic event.}

3.

B. Part/Component Functional Mode

Safety Function \#1:

[ ] Active - Mechanical or Electrical change of state is required to occur for the component to perform its safety function

[X] Passive - Change of state is not required for the component to perform its safety function Safety Function \#2:

[ ] Active - Mechanical or Electrical change of state is required to occur for the component to perform its safety function.

[X] Passive - Change of state is not required for the component to perform its safety function Safety Function \#3:

[ ] Active-Mechanical or Electrical change of state is required to occur for the component to perform its safety function.

I I Passive - Change of state is not required for the component to perform its safety function

C. Host Component Safety Function (if applicable):

1. NA

2.

3. 
Title: REOTEMP PRESSURE INDICATOR-LOCAL PRESSURE INDICATION TO MONITOR THE SCHE PURGE LINE PRESSURE AFTER THE PRV

D. Failure Mechanisms(s) and the effects on component or system safety function (see worksheet 1):

1. Fracture of the indicator body or of the piping connection - loss of SCHe in purge line.

2.

3.

4.

5.

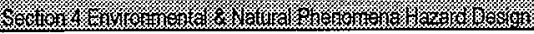

Environmental Qualification Required:

If yes: Environmental Qualification Requirements

Yes [ ]

No [X]

Limiting Environmental Conditions:

Environmental Condition B

Required Safety Functions:

Environmental Condition B

Qualification Period:

Natural Phenomena Hazard (NPH) Design Required:

If yes: NPH Design Requirements

$$
\begin{aligned}
& \text { Yes [X] } \\
& \text { No [ ] }
\end{aligned}
$$

HNF-PRO-97, Rev. 0

W-441-P5, Rev. 2
Performance Category: PC-3

NPH Design Req'ts.: Seismic Condition B

Required Safety Functions: Pressure Boundary Integrity

\section{-}

[X] Safety Class (SC)

I JGeneral Service

I ] Safety Significant (SS)

If part/component classification is dfferent from host component/system, document basis.

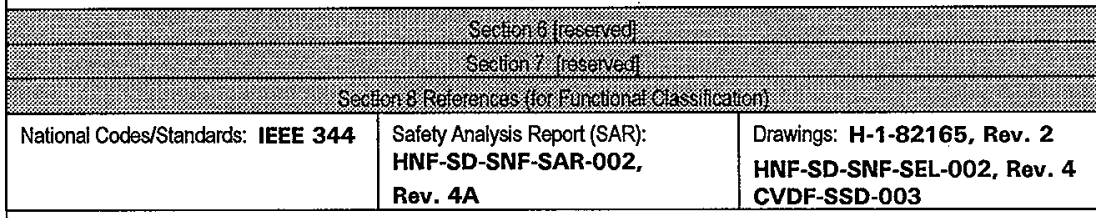

Vendor Manuals/Manufacturer/Supplier Information: Reotemp Instrument Corporation, Series PR, Stainless Steel Pressure Gauges

Other. 


ECN No. NA CGI No.CGI-SNF-D-13-P5-028
Title: REOTEMP PRESSURE INDICATOR-LOCAL PRESSURE
INDICATION TO MONITOR THE SCHE PURGE LINE PRESSURE
AFTER THE PRV

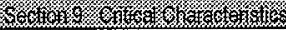

\section{Critical Characteristics}

Acceptance Criteria/Tolerances

\begin{tabular}{c|c|c}
$\begin{array}{c}\text { Acceptance } \\
\text { Method }\end{array}$ & ID & Function \\
& & \\
\end{tabular}

HNF-SD-SNF-SEL-002, Rev. 4

1. Item Identification Critical Characteristics (necessary for reasonable assurance that the ltem delivered is the ltem specified)

\begin{tabular}{|c|c|c|c|c|}
\hline Nameplate Data & Per Vendor Manual & 1, IN & $x$ & \\
\hline Model Number & PR-25-S-1-A-4-P15-D & $1, \mathrm{IN}$ & $\mathbf{x}$ & \\
\hline Manufacturer & Reotemp Instruments & $1, \mathrm{IN}$ & $\mathbf{x}$ & \\
\hline Process Connection & $\begin{array}{l}1 / 4 \text { Inch NPT with } 1 / 4 \text { Inch by } \\
1 / 2 \text { Inch Bushing; Bottom } \\
\text { Mounted }\end{array}$ & $1, \mathrm{IN}$ & $\mathbf{x}$ & \\
\hline Indicator Range & 0-15 Psig & $1, \mathbf{N}$ & $\mathbf{x}$ & \\
\hline Indicator Dial Diameter & Nominal 2.5 Inches & $1, \mathrm{IN}$ & $\underline{\mathbf{x}}$ & \\
\hline \multicolumn{5}{|c|}{ 2. Physical Critical Characteristics (necessary for reasonable assurance that the Item delivered is the Item specified) } \\
\hline Material, Body & Stainless Steel & $1, T$ & $\mathbf{x}$ & \\
\hline Material, Process Connection & Stainless Steel & $1, \mathrm{~T}$ & $\mathbf{x}$ & \\
\hline
\end{tabular}

3. Performance Critical Characteristics (necessary \& sufficient for reasonable assurance that the Item will perform its intended safety function(s))

\begin{tabular}{|c|c|c|c|}
\hline Pressure Boundary Integrity & $\begin{array}{l}\text { No Leakage at Test Pressure of } \\
165 \text { Psig. Note } 3 .\end{array}$ & $1, T$ & $x$ \\
\hline Operating Range/Accuracy & $\begin{array}{l}0-15 \text { Psig } /+/-1.6 \% \text { of Full } \\
\text { Scale. }\end{array}$ & $1, T$ & $x$ \\
\hline Environmental & Note 1 & & \\
\hline Seismic Condition B & Note 2 & $1, T$ & $\mathbf{x}$ \\
\hline \multicolumn{2}{|l|}{ 4. Notes and Legend: } & \multirow{4}{*}{\multicolumn{2}{|c|}{$\begin{array}{l}\text { Acceptance Method: } \\
\text { 1. Special Test and Inspection } \\
\text { 1,IN for Inspection } \\
\text { 1,T for Test } \\
\text { 2. Commercial Grade Survey } \\
\text { 3. Source Verification } \\
\text { 4. Vendor/lem History }\end{array}$}} \\
\hline \multicolumn{2}{|c|}{$\begin{array}{l}\text { 1. The pressure indicator is not subject to degradation at ambient } \\
\text { conditions of } 40^{\circ} \mathrm{F} \text { and } 60 \% \text { RH or } 115^{\circ} \mathrm{F} \text { and } 22 \% \mathrm{RH} \text { and is } \\
\text { suitable for Environmental Condition B application. }\end{array}$} & & \\
\hline \multicolumn{2}{|r|}{$\begin{array}{l}\text { g and after seismic event.W- } \\
1-2 \text {, provides a seismic testing } \\
\text { eismic spectra TBD. }\end{array}$} & & \\
\hline \multicolumn{2}{|c|}{$\begin{array}{l}\text { 3. Pressure test at } 110 \% \text { of system design pressure of } 150 \text { psig. } \\
\text { Exposure to test pressure may seriously degrade the readout } \\
\text { function. This test is considered to be a destructive test. }\end{array}$} & & \\
\hline
\end{tabular}


Titte: REOTEMP PRESSURE INDICATOR-LOCAL PRESSURE INDICATION TO MONITOR THE SCHE PURGE LINE PRESSURE AFTER THE PRV

Approvals:

Designated Engineer: Cuan Kamme $12 / 21 / 98$

Design Authority. Renchen 12/21198

QA Engineer:Dotap $12 / 21 / 80$ 
Commercial Grade Item Upgrade Dedication Form Rev. No. 0

ECN No. NA CGINo. CGI-SNF-D-13-P5-028

Title: REOTEMP PRESSURE INDICATOR - LOCAL PRESSURE INDICATION TO MONITOR TFE SCHE PURGE LINE PRESSURE AFTER THE PRV

\begin{tabular}{|c|c|c|}
\hline \multicolumn{3}{|c|}{$\begin{array}{c}\text { WORKSHEET } 1 \\
\text { DETERMINATION OF FAILURE MECHANISMSMODES }\end{array}$} \\
\hline \multicolumn{3}{|c|}{ 筮s } \\
\hline $\begin{array}{l}\text { Typical Failure } \\
\text { Mechanisms }\end{array}$ & Definition & $\begin{array}{l}\text { Applicable to Component } \\
\text { under Evaluation }\end{array}$ \\
\hline Fracture & $\begin{array}{l}\text { Separation of a solid accompanied by little or no } \\
\text { macroscopic plastic deformation. }\end{array}$ & $\begin{array}{l}\text { Yes [X] No [ ]; If Yes, indicate } \\
\text { failure Mode. Failure of Transmitter } \\
\text { Body or the Process Connection }\end{array}$ \\
\hline Corrosion & \multirow{2}{*}{$\begin{array}{l}\text { The gradual deterioration of a material due to } \\
\text { chemical or electrochemical reactions, such as } \\
\text { oxidation, between the material and its environment. } \\
\text { Destruction of materials by the abrasive action of } \\
\text { moving fluids, usually accelerated by the presence } \\
\text { of solid particles carried with the fluid. }\end{array}$} & $\begin{array}{l}\text { Yes [ ] No [X]; If Yes, indicate } \\
\text { failure Mode. }\end{array}$ \\
\hline Erosion & & $\begin{array}{l}\text { Yes [ ] No [X]; If Yes, indicate } \\
\text { failure Mode. }\end{array}$ \\
\hline Open Circuit & $\begin{array}{l}\text { An electrical circuit that is unintentionally broken so } \\
\text { that there is no complete path for current flow. }\end{array}$ & $\begin{array}{l}\text { Yes [ ] No [X]; if Yes, indicate } \\
\text { failure Mode. }\end{array}$ \\
\hline Short Circuit & \multirow{2}{*}{$\begin{array}{l}\text { An abnormal connection by which an electrical } \\
\text { current is connected to ground, or to some } \\
\text { conducting body, resulting in excessive current flow. } \\
\text { Clogging of a flltering mecium resulting in the } \\
\text { inability to perform its purification function or } \\
\text { blockage of flow. }\end{array}$} & $\begin{array}{l}\text { Yes [ ] No }[X] \text {; If Yes, indicate } \\
\text { failure Mode. }\end{array}$ \\
\hline Blockage & & $\begin{array}{l}\text { Yes [ ] No [X]; If Yes, indicate } \\
\text { failure Mode. }\end{array}$ \\
\hline Seizure & $\begin{array}{l}\text { Binding of a normally moving item through excessive } \\
\text { pressure, temperature, friction, jamming. }\end{array}$ & $\begin{array}{l}\text { Yes [ ] No }[X] \text {; If Yes, indicate } \\
\text { failure Mode. }\end{array}$ \\
\hline Unacceptable Vibration & \multirow{2}{*}{$\begin{array}{l}\text { Mechanical oscillations produced are beyond the } \\
\text { defined permissible limits due to unbalancing, poor } \\
\text { support, or rotation at critical speeds. } \\
\text { A loss of mechanical and physical properties of a } \\
\text { material due to exposure to high temperatures, } \\
\text { radiation exposure. }\end{array}$} & $\begin{array}{l}\text { Yes [] No N [X]; If Yes, indicate } \\
\text { failure Mode. }\end{array}$ \\
\hline Loss of Properties & & $\begin{array}{l}\text { Yes [ ] No [X]; If Yes, indicate } \\
\text { failure Mode. }\end{array}$ \\
\hline Excess Strain & $\begin{array}{l}\text { Under the action of excessive extemal forces the } \\
\text { material of the part has been deformed or distorted. }\end{array}$ & $\begin{array}{l}\text { Yes [ ] No [X]; If Yes, indicate } \\
\text { failure Mode. }\end{array}$ \\
\hline Mechanical Creep & \multirow{2}{*}{$\begin{array}{l}\text { From prolonged exposure to high temperature and } \\
\text { stress, the object will show a slow change in its } \\
\text { physical (shape and dimension) and mechanical } \\
\text { characteristics. } \\
\text { Fracture characterized by tearing of metal } \\
\text { accompanied by appreciable gross plastic } \\
\text { defomation. }\end{array}$} & $\begin{array}{l}\text { Yes [ ] No [X]; If Yes, indicate } \\
\text { failure Mode. }\end{array}$ \\
\hline Ductile Fracture & & $\begin{array}{l}\text { Yes [ ] No [X]; if Yes, indicate } \\
\text { failure Mode. }\end{array}$ \\
\hline \multicolumn{3}{|c|}{ 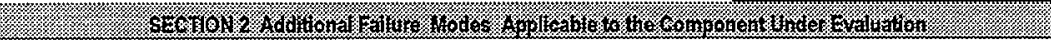 } \\
\hline \multicolumn{3}{|c|}{$\begin{array}{l}\text { 1. Process Connection/Body Break } \\
\text { 2. }\end{array}$} \\
\hline
\end{tabular}


ECN No. NA CGI No.CGI-SNE-D-13-P5-028

Title: REOTEMP PRESSURE INDICATOR - LOCAL PRESSURE INDICATION TO MONITOR THE SCHE PURGE LINE PRESSURE AFTER THE PRV

\section{CHECKLIST 1}

ACCEPTANCE METHOD 1

SPECIAL TEST/ANSPECTION VERIFICATION

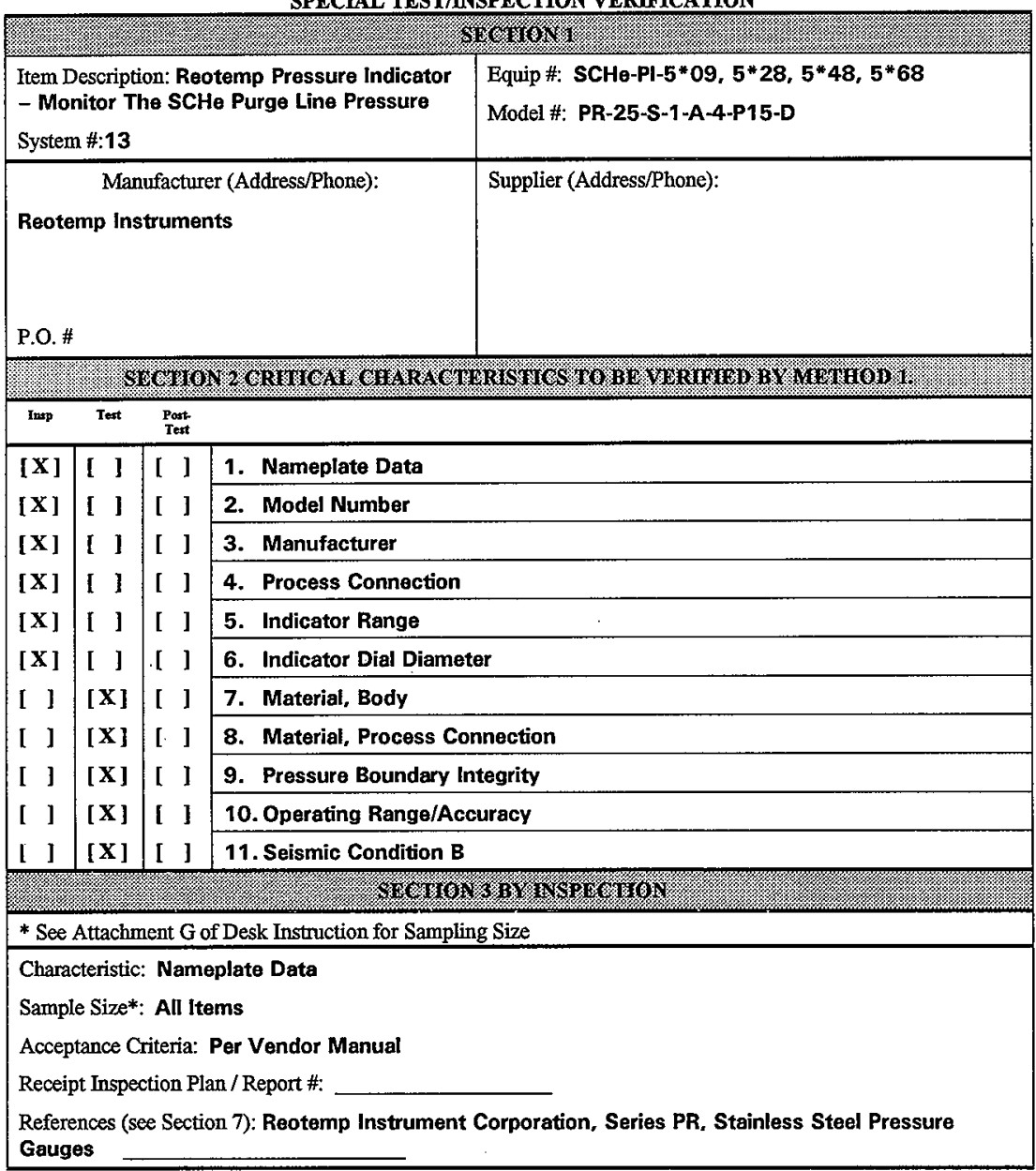


Title: REOTEMP PRESSURE INDICATOR-LOCAL PRESSURE INDICATION TO MONITOR THE SCHE PURGE LINE PRESSURE AFTER THE PRV

\section{Characteristic: Model Number}

Sample Size*: All Items

Acceptance Criteria: PR-25-S-1-A-4-P15-D

Receipt Inspection Plan/Report \#:

References (see Section 7):

Characteristic: Manufacturer

Sample Size*: All Items

Acceptance Criteria: Reotemp Instruments

Receipt Inspection Plan / Report \#:

References (see Section 7):

Characteristic: Process Connection

Sample Size*: All Items

Acceptance Criteria: 1/4 Inch NPT with $1 / 4$ Inch by $1 / 2$ Inch Bushing; Bottom Mounted

Receipt Inspection Plan / Report \#:

References (see Section 7):

Characteristic: Indicator Range

Sample Size*: All Items

Acceptance Criteria: 0-15 Psig

Receipt Inspection Plan / Report \#:

References (see Section 7):

Characteristic: Indicator Dial Diameter

Sample Size*: All Items

Acceptance Criteria: Nominal 2.5 Inches

Receipt Inspection Plan / Report \#:

References (see Section 7): 


\section{Title: REOTEMP PRESSURE INDYCATOR - LOCAL PRESSURE INDICATION TO MONITOR THE SCHE PURGE LINE PRESSURE AFTER THE PRV}

\section{4.}

\section{* See Attachment G of Desk Instruction for Sampling Size}

Test To Be Performed by:

Number of Items to be Tested:

[ ] Purchaser

[ ] Supplier/Manufacturer**

Test/Inspection Location:

[ ] Other

Characteristic for Test: Material, Body

Acceptance Criteria: Stainless Steel

Sample Size*: Normal Sampling Size

Actual Test Value:

Test Plan and Report \#: References (see Section 7):

Characteristic for Test: Material, Process Connection

Acceptance Criteria: Stainless Steel

Sample Size*: Normal Sampling Size

Actual Test Value:

Test Plan and Report \#:

References (see Section 7):

\section{Characteristic for Test: Pressure Boundary Integrity}

Acceptance Criteria: No Leakage at Test Pressure of 165 Psig.

Sample Size*: Destructively Test Only One Item

Actual Test Value:

Test Plan and Report \#: References (see Section 7):

\section{Characteristic for Test: Operating Range/Accuracy}

Acceptance Criteria: 0-15 Psig $/+/-1.6 \%$ of Full Scale.

Sample Size*: Normal Sampling Size

Actual Test Value:

Test Plan and Report \#:

References (see Section 7):

Characteristic for Test: Seismic Condition B

Acceptance Criteria: Maintain Pressure Boundary After Seismic Event. W-441-P5, Rev. 2, Appendix I, page 1-2, provides a seismic Testing plan for these components at a seismic spectra TBD.

Sample Size*: Normal Sampling Size

Actual Test Value:

Test Plan and Report \#: References (see Section 7):

**If Supplier/Manufacturer or Other, Refer to CGI Checklist-2 for Support Information 


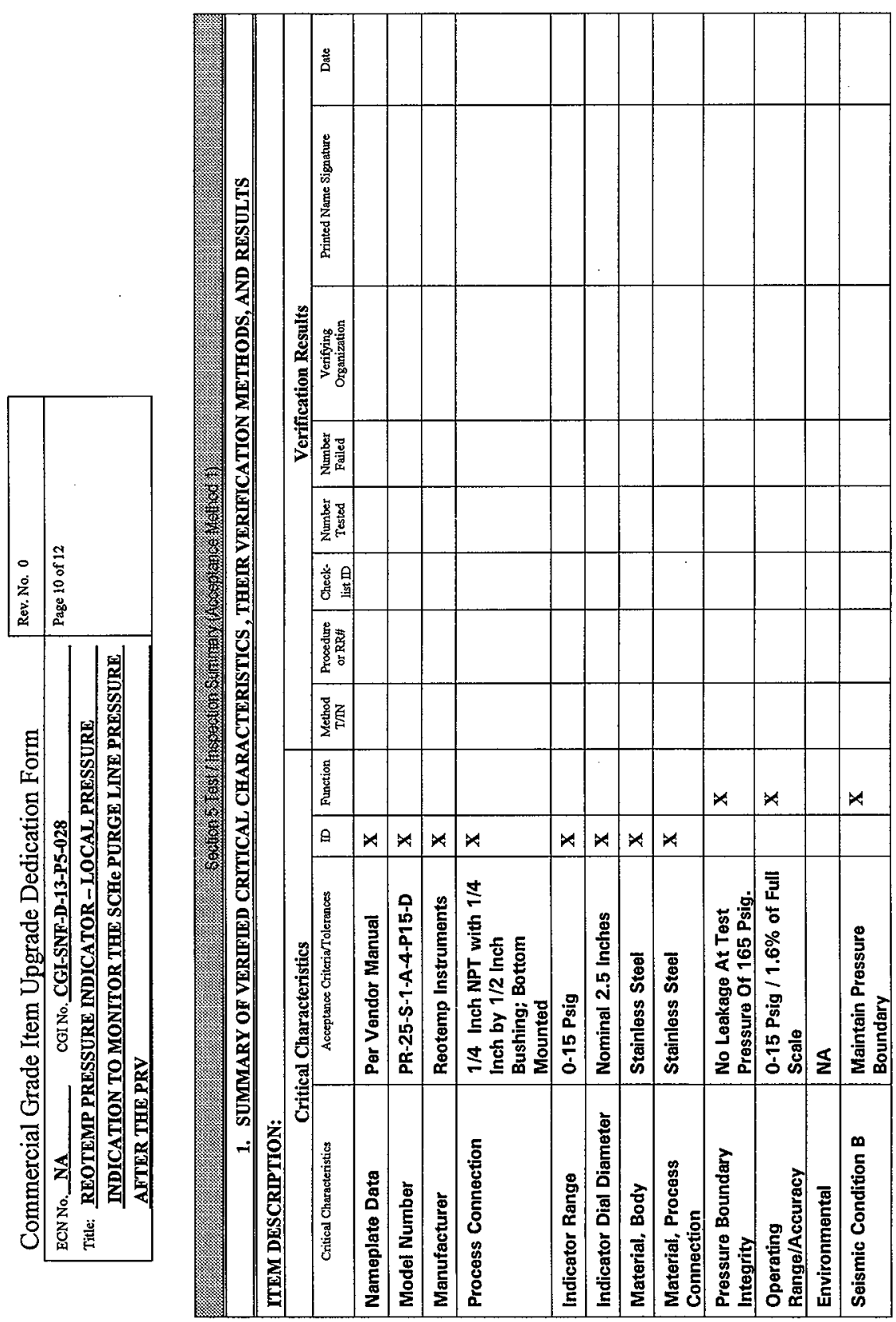




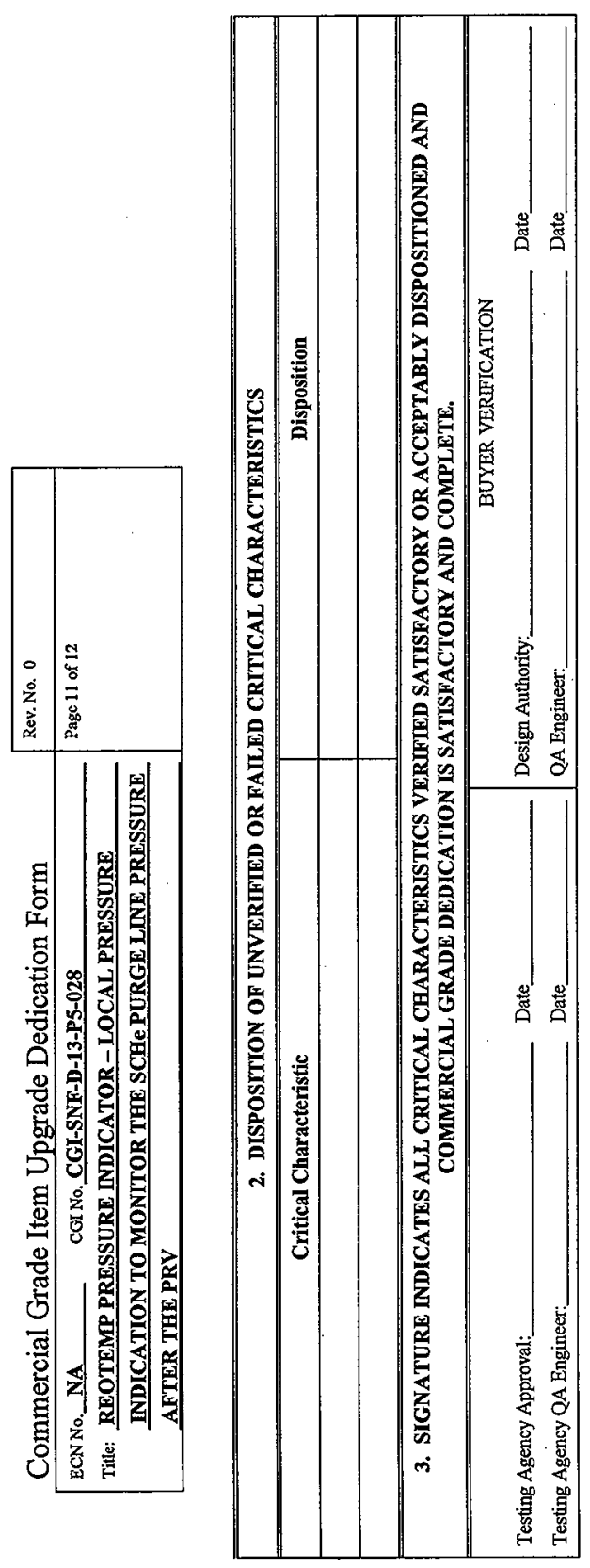


'Commercial Grade Item Upgrade Dedication Form

ECN No. NA CGI No.CGI-SNF-D-13-P5-028

Rev. No. 0

SNF-3925

Title: REOTEMP PRESSURE INDICATOR-LOCAL PRESSURE INDICATION TO MONITOR THE SCHE PURGE LINE PRESSURE AFTER THE PRV

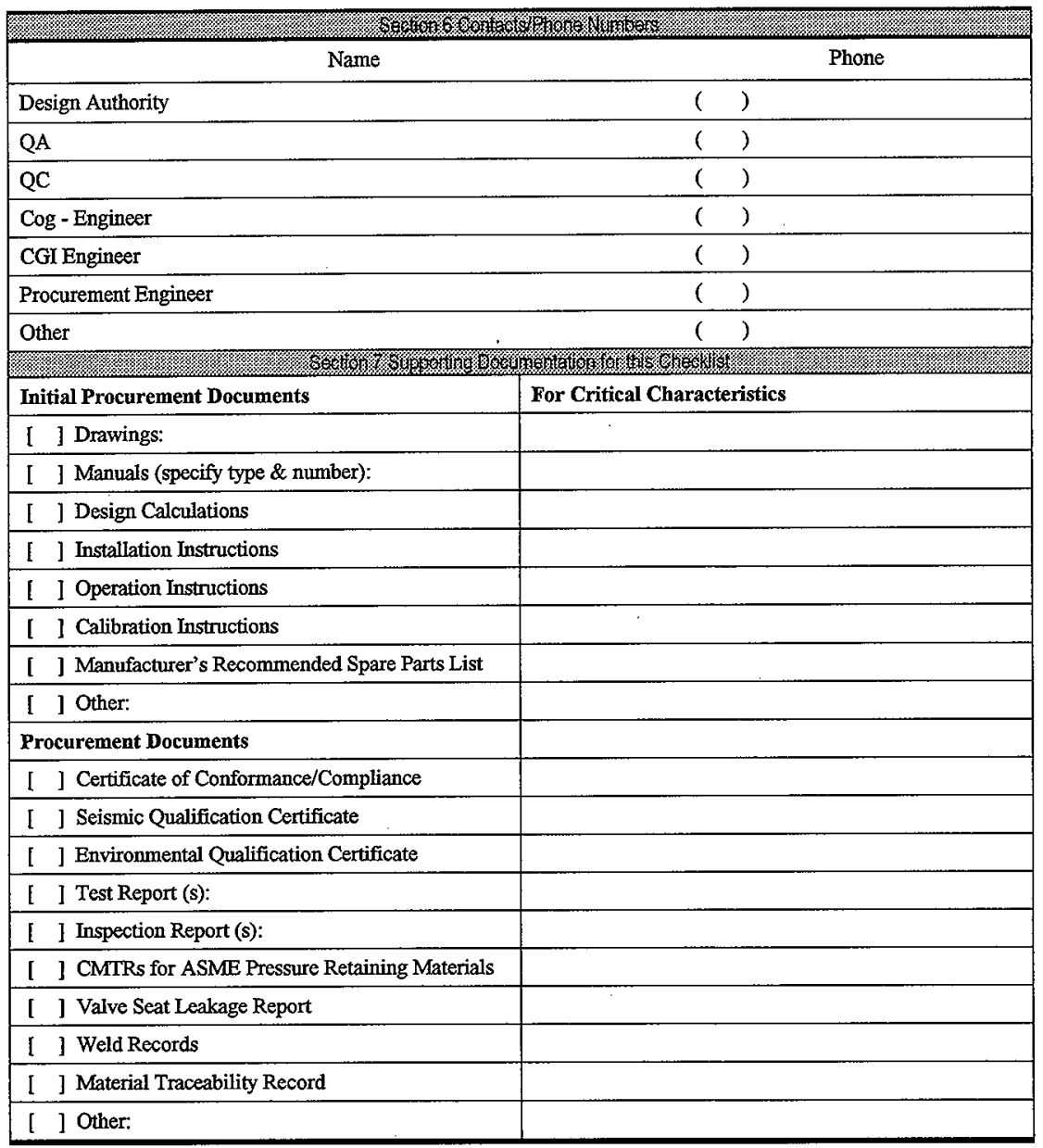

